\title{
Climatic warming, glacier recession and runoff from Alpine basins after the Little Ice Age maximum
}

\author{
David N. COLLINS \\ School of Environment \& Life Sciences, University of Salford, Salford Crescent, Manchester M5 4WT, UK \\ E-mail: d.n.collins@salford.ac.uk
}

\begin{abstract}
Records of discharge of rivers draining Alpine basins with between 0 and $\sim 70 \%$ ice cover, in the upper Aare and Rhône catchments, Switzerland, for the period 1894-2006 have been examined together with climatic data for 1866-2006, with a view to assessing the effects on runoff from glacierized basins of climatic warming coupled with glacier recession following the Little Ice Age maximum. Annual runoff from ice-free basins reflects precipitation variations, rising from minima between 1880 and 1910 to maxima between the late 1960s and early 1980s. The more highly glacierized the basin, the more runoff mimicked mean May-September air temperature during two periods of warming. Runoff increased gradually from the 1900s, rapidly in the 1940s, before decreasing to the late 1970s. Rising runoff levels during the second warming period failed to exceed those attained during the first, despite higher summer temperatures. Although temperatures continued to rise, discharge from glacierized basins declined after reaching maxima in the late 1980s to early 1990s. In the first warming period, rising specific melt rates augmented by increasing precipitation opposed the impact of declining glacier area on runoff. Although melt continued to increase in the second period, enhanced melting (even in the exceptionally warm summer of 2003) appears to have been insufficient to offset reducing glacier surface area exposed to melt, low or reducing levels of precipitation, and increasing evaporation. Thus runoff from glacierized basins peaked in the late 1940s to early 1950s.
\end{abstract}

\section{INTRODUCTION}

During a period of sustained climatic warming, runoff from glaciers might be expected first to increase as a result of enhanced melting of snow and ice, as suggested by Jansson and others (2003). Meltwater discharge would not, however, continue to increase indefinitely, as, during progressively warmer summers, declining glacier extent will reduce the surface area of ice over which energy exchange can occur. As glaciers recede, a component of flow in excess of that related to contemporary precipitation, a deglaciation discharge dividend, is added to basin runoff from depletion of the amount of water stored as ice. That dividend will decline, and ultimately cease, as glaciers disappear altogether. Basin runoff will then solely reflect future levels of precipitation. Runoff from ice-free portions of glacierized basins, as from ice-free basins, is directly influenced by temporal changes in the water balance, i.e. precipitation minus evaporation. Hence, the lower the percentage basin glacierization, the more year-to-year variations in runoff will be influenced by those of precipitation, and, conversely, the higher the glacierization the more runoff variation will reflect temporal variations in heat energy available for melt and changes in glacier dimensions (Collins, 1989).

The aim of this paper is to examine temporal variations in climatic conditions and runoff from the end of the 19th century (where records are available) through the 20th and into the 21 st century for Alpine basins, with a view to ascertaining whether, as climate warmed, runoff from glacierized basins continued to increase, or, having reached peak levels, flow had started to decline, as glaciers receded from maximum dimensions attained during the Little Ice Age (LIA), reached around 1850 (Maisch and others, 1999; Vincent and others, 2005). Runoff from two (near-)ice-free basins with ice cover between 0 and $2 \%$ have been examined in order to provide a yardstick against which to assess changes in flow arising from climatic influences and ice depletion in three glacierized basins with (in 2002) 36-66\% of catchment area ice-covered.

Underlying patterns of runoff from partially glacierized Alpine basins fluctuated considerably in response to two cycles of warming during the 20th century (Collins, 2006). Cumulative loss of ice mass generally continued to reduce glacier size, including during the intervening mid-century cooler period. By 1934, glacier surface area in the upper Rhône basin, above Lac Leman, had already been reduced by $88.8 \mathrm{~km}^{2}\left(9.5 \%\right.$ of the total ice cover) from $930.4 \mathrm{~km}^{2}$ $\left(17.9 \%\right.$ of the basin glacierized) in 1876 . A further $95 \mathrm{~km}^{2}$ was lost by 1973 , leaving $746.6 \mathrm{~km}^{2}$ (14.4\% glacierized), an overall reduction in glacier-covered area of $19.8 \%$ from 1876 (Kasser, 1981). Several warm summers in which runoff from glacierized basins was enhanced with respect to surrounding years are prominent in the records. For example, during the second warming cycle the summer of 2003 was exceptionally warm in the Alps (Beniston, 2004), mean summer temperatures exceeding those of the previous warmest summer, that of 1947, in the first cycle.

\section{CHARACTERISTICS OF BASINS AND MEASUREMENTS}

Locations of the study basins in the upper Aare and upper Rhône basins in Switzerland are shown in Figure 1. Characteristics of the basins are given in Table 1, and elevation ranges of the catchments and of included glacierized areas are shown in Figure 2. Percentage glacierization of basin area was taken from the contemporary annual Hydrologisches Jahrbuch der Schweiz (e.g. BAFU, 2006). The Allenbach basin is ice-free. The Grande Eau basin, into which since 


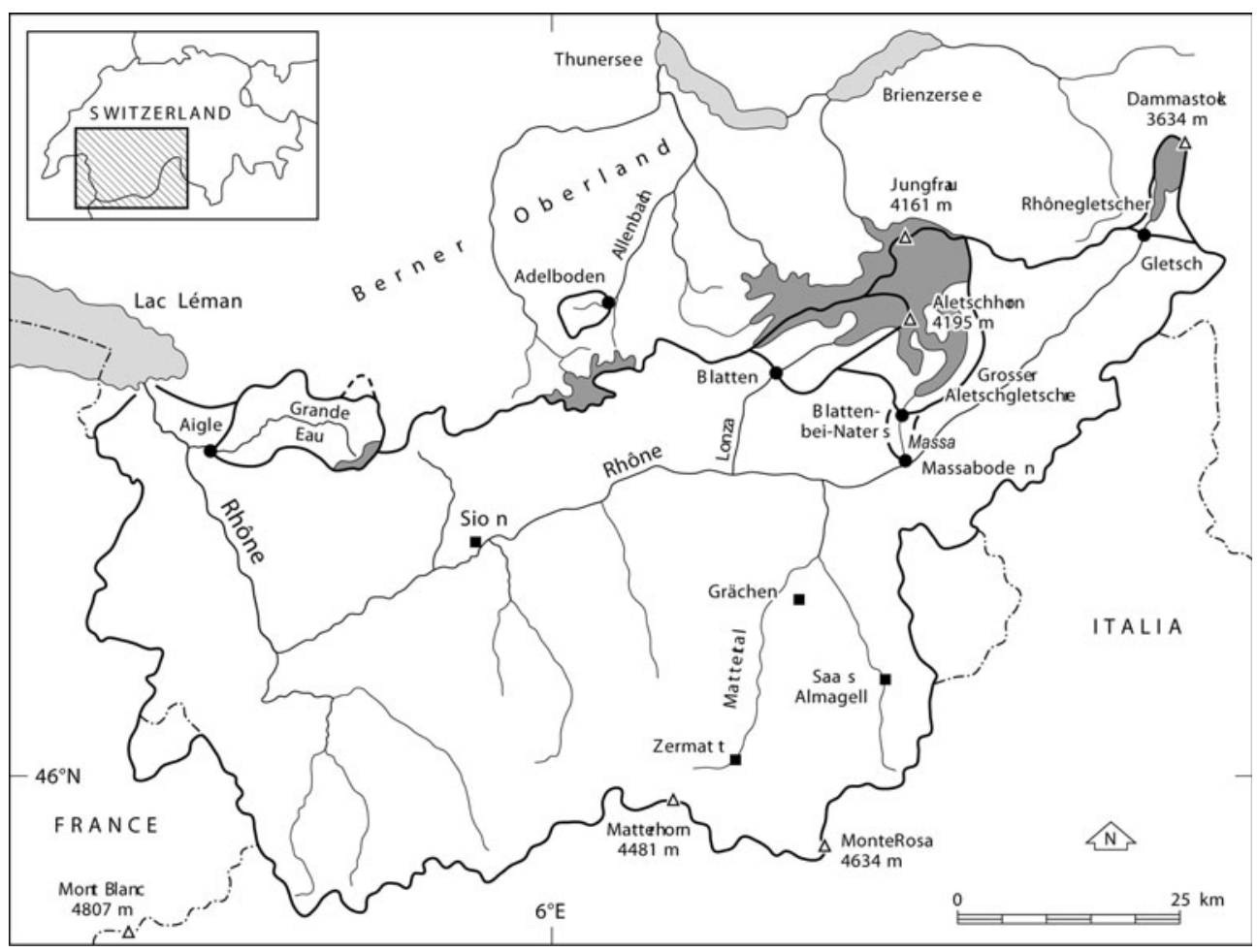

Fig. 1. Locations of study basins in the upper Rhône and upper Aare catchments, Switzerland. Gauging and meteorological stations from which records have been used are indicated. Glacierized areas within and around the study basins are shaded.

1942 some water has been transferred from the adjacent Arnensee basin, whilst containing Glacier de Pierredar $\left(1.25 \mathrm{~km}^{2}\right.$ in 1973), is almost ice-free. The Rhône was gauged in a natural cross-section at Gletsch between 1894 and 1903, and again between 1920 and 1928, before use of a flume structure from 1956. Total glacier-covered areas of about 32 and $22 \mathrm{~km}^{2}$ in the Lonza, gauged also from 1956, and Rhône basins declined by about $10 \%$ and $7.5 \%$ respectively between 1977 and 2002. Following dam construction, from 1965 the Massa was gauged at Blatten-bei-Naters, upstream of the former station at Massaboden, reducing basin area by $3.47 \%$. Runoff at the Blatten gauge is unlikely to have been proportionally reduced, as the area of basin excluded was both ice-free and at low elevation, with consequent relatively low precipitation. Percentage glacierization of the Massa basin, recalculated to take into account catchment area change (Table 1 ), reflects a loss of total icecovered area of about $8 \mathrm{~km}^{2}(6 \%)$ from $136.6 \mathrm{~km}^{2}$ between 1934 and 2002, of which about three-quarters had disappeared by 1957 . Total annual runoff was taken as the total for the calendar year $\left(Q_{1-12}\right)$.

Mean May-September air temperature $\left(T_{5-9}\right)$ was used to indicate heat-energy availability for melting. $T_{5-9}$ recorded at Sion (Couvent des Capucins), although located at only 549 m a.s.l., has been shown to have high correlation with $Q_{1-12}$ from glacierized basins throughout the upper Rhône

Table 1. Characteristics of the study basins

\begin{tabular}{|c|c|c|c|c|c|}
\hline \multirow[t]{2}{*}{ River/gauging station } & \multirow[t]{2}{*}{ Principal glacier } & \multirow{2}{*}{$\begin{array}{c}\text { Basin area } \\
\mathrm{km}^{2}\end{array}$} & \multirow{2}{*}{$\begin{array}{c}\text { Mean annual runoff, } \\
\text { 1956-2005 } \\
\text { m }\end{array}$} & \multicolumn{2}{|c|}{ Basin glacierization } \\
\hline & & & & year & $\%$ \\
\hline Allenbach/Adelboden & & 28.8 & 1.312 & & 0.0 \\
\hline Grande Eau/Aigle (+Arnensee) & Glacier de Pierredar & $132.0(139.1)$ & 1.190 & $\begin{array}{l}1977 \\
2002\end{array}$ & $\begin{array}{l}1.9(1.8) \\
1.8(1.7)\end{array}$ \\
\hline Lonza/Blatten & Langgletscher & 77.8 & 1.905 & $\begin{array}{l}1977 \\
2002\end{array}$ & $\begin{array}{l}40.6 \\
36.5\end{array}$ \\
\hline Rhône/Gletsch & Rhônegletscher & 38.9 & 2.218 & $\begin{array}{l}1977 \\
2002\end{array}$ & $\begin{array}{l}56.4 \\
52.2\end{array}$ \\
\hline Massa/Massaboden & $\begin{array}{c}\text { Grosser } \\
\text { Aletschgletscher }\end{array}$ & 202.0 & & $\begin{array}{l}1927 \\
1934 \\
1957\end{array}$ & $\begin{array}{l}68.3 \\
67.6 \\
64.1\end{array}$ \\
\hline Massa/Blatten-bei-Naters & & 195.0 & 2.112 & $\begin{array}{l}1957 \\
1977 \\
2002\end{array}$ & $\begin{array}{l}66.4 \\
66.6 \\
65.9\end{array}$ \\
\hline
\end{tabular}




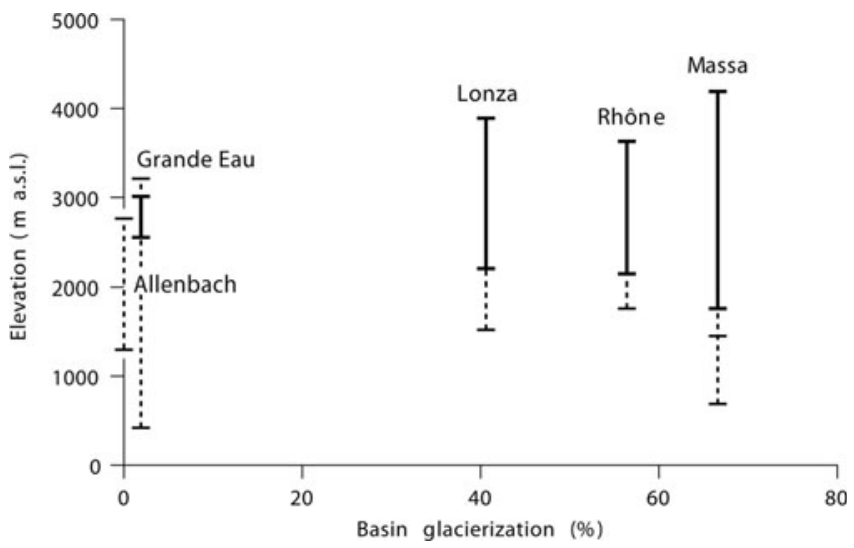

Fig. 2. Elevations of gauging stations, lower and upper limits of glacierized areas (solid lines) and highest points in each study basin plotted against percentage basin glacierization.

catchment (Collins, 1989). The station recorded from 1866, not long after glaciers had started to decline from the LIA maximum, but closed in 1977. Collins $(1989,2006)$ estimated subsequent annual values of $T_{5-9}$ for Sion from observations at Grächen (1617 ma.s.I.) and Saas Almagell (1669 ma.s.l.). Homogenized temperature data are now produced for Sion (for the station Sion Aéroport (actual observations from 1978 onwards) at $482 \mathrm{~m}$ a.s.l.) by MeteoSchweiz (Bader and Bantle, 2004; Begert and others, 2005). Correlation between $T_{5-9}$ data used by Collins (2006) and respective values taken from the homogeneous series is high $(r=0.94 ; 1866-2006)$; the homogeneous series is used in this paper.

Total annual precipitation between November in one year and October in the next $\left(P_{11-10}\right)$ reflects build-up of winter snowpack and summer rainfall which affect total annual discharge between January and December $\left(Q_{1-12}\right)$ in the second year. Long series are available from Sion for 18651977 and Zermatt for 1893-1922 at $1609 \mathrm{~m}$ and for 19262006 at 1632 ma.s.l., the latter series preferred by Collins (1989), being at higher elevation and covering the second warming period. Homogenized monthly precipitation data from MeteoSchweiz for Sion Aéroport now provide an extended series at one location. Correlation between homogenized data for Sion and actual data from Zermatt is weak ( $r=0.48 ; 1893-2006)$, reflecting the natural spatial variability in year-to-year total annual precipitation in mountainous terrain.

\section{YEAR-TO-YEAR VARIATIONS OF CLIMATIC VARIABLES AND RUNOFF}

After a decade of summer air temperatures above the longterm average $\left(16.37^{\circ} \mathrm{C}\right), T_{5-9}$ declined until the $1890 \mathrm{~s}$ (Fig. 3). After the warm summer of $1911\left(17.4^{\circ} \mathrm{C}\right)$, from a minimum of $14.1^{\circ} \mathrm{C}$ in 1912 , summer temperatures generally increased until the late 1940s-early 1950s, the first warming cycle, with a maximum of $18.7^{\circ} \mathrm{C}$ in 1947 , before declining until the late $1970 \mathrm{~s}$ with a minimum of $15.0^{\circ} \mathrm{C}$ in 1978. A second warming period, from the 1980 s to the early 21 st century, included the warmest summer $\left(19.9^{\circ} \mathrm{C}\right.$ in 2003 ) in the 1866-2006 record, on an underlying gently rising linear trend of $\sim 0.015^{\circ} \mathrm{Ca}^{-1}$ from the $1880 \mathrm{~s}$. The second warming period appears to have been associated
Table 2. Matrix of correlation coefficients for the relationships between meteorological variables recorded at Sion and total annual runoff $\left(Q_{1-12}\right)$

\begin{tabular}{|c|c|c|c|c|c|c|}
\hline & \multirow[t]{2}{*}{ Period } & \multicolumn{5}{|c|}{$Q_{1-12}$} \\
\hline & & Massa & Rhône & Lonza & Grande Eau & Allenbach \\
\hline \multirow{6}{*}{$P_{11-10}$} & 1894-1903 & & -0.01 & & & \\
\hline & 1894-2006 & & 0.13 & & & \\
\hline & 1920-28 & 0.03 & 0.13 & & & \\
\hline & 1923-2006 & -0.13 & 0.29 & & & \\
\hline & 1931-2006 & -0.15 & & & 0.67 & \\
\hline & 1956-2006 & 0.01 & 0.28 & 0.27 & 0.69 & 0.61 \\
\hline \multirow{6}{*}{$T_{5-9}$} & 1894-1903 & & 0.44 & & & \\
\hline & 1894-2006 & & 0.40 & & & \\
\hline & 1920-28 & 0.95 & 0.55 & & & \\
\hline & 1923-2006 & 0.78 & 0.57 & & & \\
\hline & 1931-2006 & 0.83 & & & -0.15 & \\
\hline & 1956-2006 & 0.90 & 0.68 & 0.23 & -0.18 & 0.00 \\
\hline
\end{tabular}

with sustained high-pressure anomalies over central Europe (Beniston and Jungo, 2002).

$P_{11-10}$ showed considerable year-to-year fluctuation (Fig. 3). After several wet years in the 1860s-70s, precipitation at Sion from the 1880s to 1900 s was generally below the long-term average of $571 \mathrm{~mm}$, although 1895/96 $(948 \mathrm{~mm})$ was the wettest year in the series (the second wettest at Zermatt $(1062 \mathrm{~mm}))$. Between the 1900s and 1950s, precipitation varied about a slightly rising trend, but with several exceptionally dry $(226 \mathrm{~mm}$ in 1920/21, $323 \mathrm{~mm}$ in 1924/25) and wet years $(817 \mathrm{~mm}$ in $1944 / 45)$ at Sion. The cool 1970s had both dry $(1971 / 72,1975 / 76)$ and wet years (1976/77-1979/80) but with no trend through to the warm 1990s-2000s, which included the second wettest year in the record (894 $\mathrm{mm}$ in 1989/90) but with several years below average (e.g. 1988/89 and 2003/04). $P_{11-10}$ for Sion showed little relation to $T_{5-9}(r=-0.11 ; 1866-2006)$. After the wet years from the mid-1970s to $1981 / 82, P_{11-10}$ for Zermatt declined, with the majority of annual values below the station average, including 1989/90.

Annual total runoff from the (near-)ice-free basins of Allenbach and Grande Eau generally reflected the temporal variation of precipitation, rising to maxima in the late 1970s-early 1980 s and late 1960 s respectively (Fig. 3). $P_{11-10}$ at Sion was reasonably correlated with $Q_{1-12}$ of both Grande Eau and Allenbach $(r>0.6$; Table 2). Year-to-year fluctuations of runoff in the two basins were broadly parallel until the 1990s ( $r=0.84$; Table 3). Mean decadal flow in the Allenbach and Grande Eau declined by $11 \%$ and $16 \%$ respectively from 1977-86 to 1997-2006, in the Grande Eau more strongly reflecting $P_{11-10}$ for Zermatt $(r=0.64$; $1935-$ 2006) than for Sion.

Runoff in the Massa, which drains the most highly icecovered of the glacierized basins, mimicked the cyclical pattern of variation in $T_{5-9}$ at Sion (Fig. 3). The correlation between $T_{5-9}$ and $Q_{1-12}$, whilst generally strong, was greater the shorter the time period considered (Table 2). Correlation between runoff from Grosser Aletschgletscher and $P_{11-10}$ at Sion was slightly negative or undefined. High discharge in $1928\left(587.54 \times 10^{6} \mathrm{~m}^{3}\right)$ resulted from a warm spring, masked by overall summer temperature $\left(16.7^{\circ} \mathrm{C}\right)$ ranked only sixth highest in the series to date from 1864, but with 

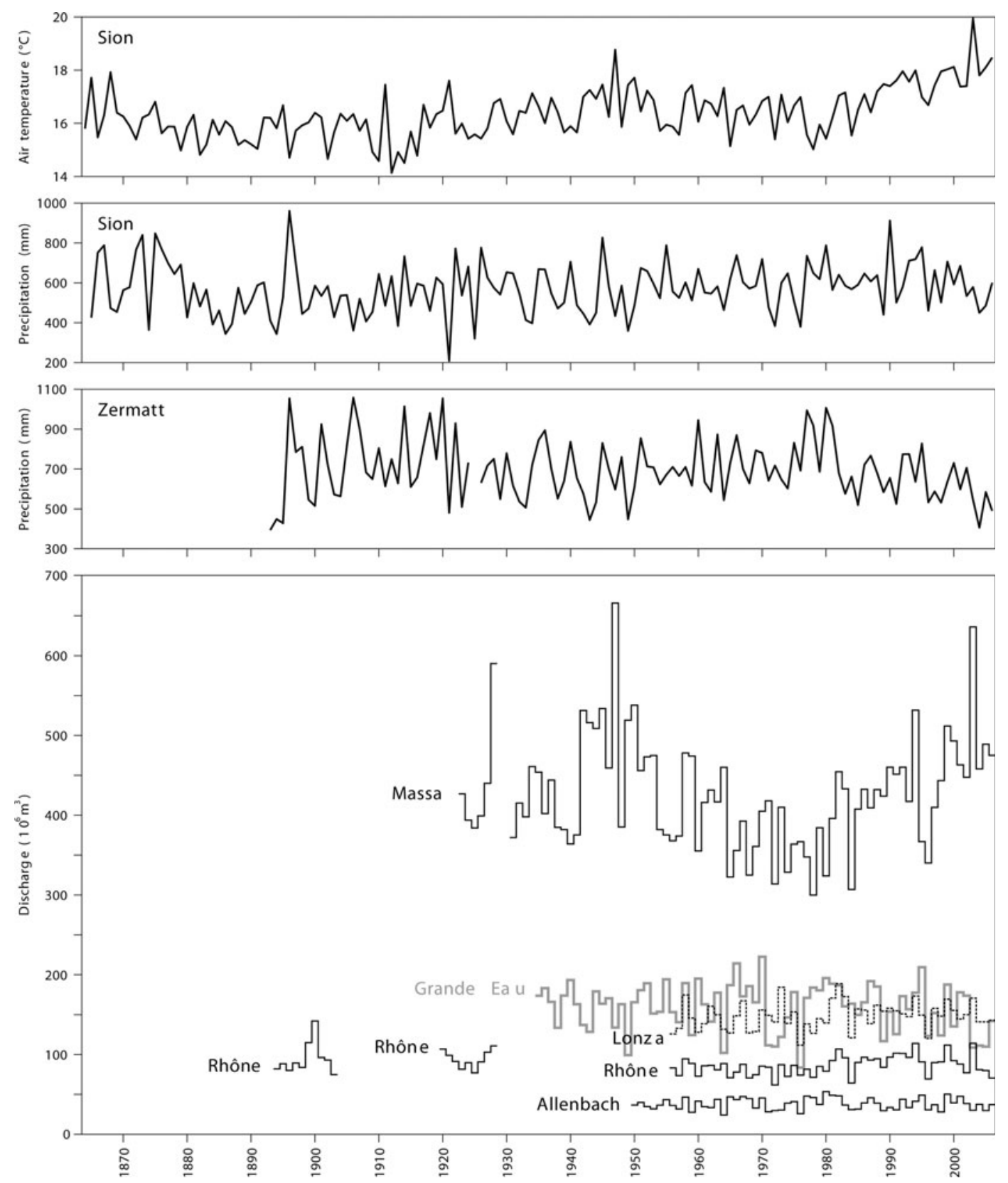

Fig. 3. Year-to-year variations of mean summer air temperature $\left(T_{5-9}\right)$ at Sion, annual total precipitation between November and October $\left(P_{11-10}\right)$ at Sion and Zermatt, and annual total discharge between January and December $\left(Q_{1-12}\right)$ of the Allenbach, Grande Eau, Lonza, Massa and Rhône in the period 1866-2006. Discharge measurements of the Massa were interrupted in 1929 and 1930, and two short discrete periods of measurement preceded the continuous record of the Rhône.

precipitation slightly above average. Rising temperatures, together with increasing precipitation, led to runoff generally increasing over subsequent years, with a maximum in 1947. Declining summer air temperatures next reduced runoff to a minimum in 1978. During the second warming cycle, temperatures exceeded those experienced in the 1940s. However, mean discharge in the warmer 1990s2000s (mean $T_{5-9} 17.9^{\circ} \mathrm{C}, Q_{1-12} 482.84 \times 10^{6} \mathrm{~m}^{3}$ for $1997-$ 2006) failed to exceed that of the 1940s-50s (mean $T_{5-9}$ $17.1^{\circ} \mathrm{C}, Q_{1-12} 505.96 \times 10^{6} \mathrm{~m}^{3}$ for 1943-52) (Fig. 3).

The discontinuous record of discharge of the Rhône at Gletsch, draining the second most highly glacierized of the study basins, extends through the cool 1890s, part of the first warming period, the intervening cool and the second warming period (Fig. 3). Correlation of $T_{5-9}$ at Sion with runoff in the Rhône was not as strong as for flow in the
Massa, whereas correlation of $P_{11-10}$ with runoff was more positive for the Rhône, for respective periods (Table 2). Runoff in the two rivers was strongly correlated (Table 3). Discharge in the Rhône also increased from the cooler 1960 s-70s to the warmer 1980s-2000s but by only $12 \%$, whereas quinquennial average annual runoff in the Massa increased by almost 50\% between $1974-78$ and 2001-05, accompanying a rise in mean $T_{5-9}$ from $16.1^{\circ} \mathrm{C}$ to $18.1^{\circ} \mathrm{C}$. In fact, runoff at Gletsch increased from an average of $87.61 \times 10^{6} \mathrm{~m}^{3}$ in $1977-86$ to $94.32 \times 10^{6} \mathrm{~m}^{3}$ (1987-96), before decreasing to $91.05 \times 10^{6} \mathrm{~m}^{3}$ in $1997-2006$. The maximum annual discharge of the Rhône in the years for which observations are available was attained in 1900 $\left(141.00 \times 10^{6} \mathrm{~m}^{3}\right)$, a level substantially greater than other high flows. This value was probably an anomaly. Precipitation was unexceptional, and $T_{5-9}$ in $1900\left(16.4^{\circ} \mathrm{C}\right)$ was 
lower than in both $1895\left(16.6^{\circ} \mathrm{C}\right)$ and $1928\left(16.7^{\circ} \mathrm{C}\right)$, in which years runoff was $88.50 \times 10^{6}$ and $110.53 \times 10^{6} \mathrm{~m}^{3}$ respectively. In 1928, discharge was also prominent in the Massa record.

The pattern of temporal variation of discharge in the Lonza ( $38 \%$ glacierized) was to an extent intermediate between that in the Allenbach ( $0 \%$ ) and the Rhône ( $54 \%)$. Correlation with $T_{5-9}$ at Sion was weaker than for the more highly glacierized basins, and with $P_{11-10}$ weaker than for the (near-)ice-free basins (Table 2). Correlation of runoff in the Lonza with that in the Rhône was, however, greater than with that in rivers draining the (near-)ice-free basins (Table 3). Runoff in the Lonza increased between 1977-86 (147.01 $\times$ $\left.10^{6} \mathrm{~m}^{3}\right)$ and 1987-96 $\left(154.42 \times 10^{6} \mathrm{~m}^{3}\right)$, before decreasing in 1997-2006 $\left(149.95 \times 10^{6} \mathrm{~m}^{3}\right)$ (Fig. 3).

\section{DISCUSSION}

Whether runoff from the ice-covered portion of a basin increases through time during sustained climatic warming coupled with deglaciation depends on the extent to which the increasing specific melt rate can offset reduction in glacier surface area exposed to melt. Year-to-year changes in runoff from an entire glacierized basin, however, depend also on variations in precipitation-influenced runoff from the ice-free area and temperature-influenced evaporation across the entire basin. Should a downturn in precipitation occur during a warming period, the trend in total basin runoff will depend on the sum of the contributions to runoff of increasing melt over the declining glacier area and declining precipitation in the enlarging ice-free area, as well as losses arising from enhancing evaporation.

In the first warming period, flow in the Massa increased, as enhanced melt rates under rising temperatures (up $1.3^{\circ} \mathrm{C}$ between 1922-28 and 1943-52) together with increasing precipitation were more than adequate to offset the effect of declining glacier area on total meltwater production. Reduction in runoff in both (near-)ice-free Allenbach and Grande Eau during the second warming period suggests that evaporation increased and precipitation declined. Flow in the Grande Eau declined by 10.4\% between 1943-52 and 1997-2006. Precipitation records at Sion and Zermatt are, however, not unequivocal, mean $P_{11-10}$ at Sion increasing by $6.4 \%$ but at Zermatt declining by $11.4 \%$ between the two 10 year periods. Runoff from the highly glacierized Massa basin declined by $4.5 \%$, suggesting that the mean temperature rise of $0.8^{\circ} \mathrm{C}$ between the two periods produced melt rates not quite sufficient fully to offset precipitation, evaporation and ice area losses. Decrease in surface area of Grosser Aletschgletscher, however, was small (7.0\%)
Table 3. Matrix of correlation coefficients for the relationships between total annual runoff $\left(Q_{1-12}\right)$ for the rivers/stations listed in Table 1 in the period 1956-2005

\begin{tabular}{lrccc}
\hline & Allenbach & Grande Eau & Lonza & Rhône \\
\hline Grande Eau & 0.84 & & & \\
Lonza & 0.20 & 0.15 & & \\
Rhône & 0.12 & 0.07 & 0.76 & \\
Massa & -0.17 & -0.25 & 0.61 & 0.84 \\
& & & & \\
\hline
\end{tabular}

between 1927 and 2002 (Table 1). In the long record for the Massa, 1928, 1947 and 2003 stand out as years in which runoff was prominent (Fig. 3). Characteristics and rank orders of air temperature, precipitation and runoff in these years are given in Table 4 . Despite a difference in air temperature of $3.2^{\circ} \mathrm{C}$, discharge in the Massa was increased above that in 1928 by $<10 \%$ in 2003 and by $13 \%$ in 1947 . Runoff in the Massa in 2003 was about $4 \%$ below that in 1947 , although $T_{5-9}$ had increased by $1.2^{\circ} \mathrm{C}$.

Between 1929 and 1955, discharge of the Rhône at Gletsch was not measured, so that runoff data are missing for the warm year of 1947, but, neglecting the 1900 measurement as unreliable, 1920, 1928, 1994 and 2003 are prominent in the record. The terminus of Rhônegletscher retreated $\sim 0.6 \mathrm{~km}$ between 1900 and 1955, and a further $\sim 0.2 \mathrm{~km}$ by 1990 (Landeshydrologie, Bundesamt für Wasser und Geologie, 1999). Total discharge $\left(Q_{1-12}\right)$ in the Rhône in these prominent years was in a limited range between $107.1 \times$ $10^{6} \mathrm{~m}^{3}(1920)$ and $114.49 \times 10^{6} \mathrm{~m}^{3}$ (2003) for a temperature difference of $3.4^{\circ} \mathrm{C}$. Estimates of total flow in the Rhône in 1947 by regression against $T_{5-9}$ at Sion and $Q_{1-12}$ in the Massa are in the range $110-133 \times 10^{6} \mathrm{~m}^{3}$. Average runoff in the Rhône increased by $0.146 \times 10^{6} \mathrm{~m}^{3}$ to $94.317 \times 10^{6} \mathrm{~m}^{3}$ between the periods 1922-28 and 1987-96, associated with a summer temperature increase from $15.8^{\circ} \mathrm{C}$ to $17.3^{\circ} \mathrm{C}$. $Q_{1-12}$ of the Lonza in peak years also varied in a restricted range, being lower in 2003 than in $1982\left(T_{5-9}=17.1^{\circ} \mathrm{C}\right)$. Meltwater production on Langgletscher, which was reduced in area by $10 \%$ between 1977 and 2002, was insufficient, even in the warmest year, to offset reduced precipitation.

What happened to river flow from glacierized basins in the second half of the 19th century, following the LIA maximum, remains conjectural. A substantial precipitation decrease probably led to initiation of glacier recession (Vincent and others, 2005). Precipitation continued to decline to the 1880s-1900s. River flow from glacierized basins probably increased gradually with rising summer air

Table 4. Hydrological and climatic characteristics of years in which runoff in the Massa was prominent, with rank orders from highest to lowest

\begin{tabular}{|c|c|c|c|c|c|c|c|c|}
\hline \multirow[t]{3}{*}{ Year } & \multicolumn{2}{|c|}{$Q_{1-12}$ for Massa } & \multicolumn{2}{|c|}{$T_{5-9}$ for Sion } & \multicolumn{2}{|c|}{$P_{11-10}$ for Zermatt } & \multicolumn{2}{|c|}{$P_{11-10}$ for Sion } \\
\hline & Rank order & Value & Rank order & Value & Rank order & Value & Rank order & Value \\
\hline & & $10^{6} \mathrm{~m}^{3}$ & & ${ }^{\circ} \mathrm{C}$ & & $\mathrm{mm}$ & & $\mathrm{mm}$ \\
\hline 1928 & 3 & 590.23 & 3 & 16.7 & 1 & 754.0 & 2 & 572.6 \\
\hline 1947 & 1 & 665.46 & 2 & 18.7 & 2 & 586.0 & 3 & 437.5 \\
\hline 2003 & 2 & 636.70 & 1 & 19.9 & 3 & 545.2 & 1 & 578.1 \\
\hline
\end{tabular}


temperatures from the 1880s to the 1940s. Assessed from an estimated basin water balance, Grosser Aletschgletscher had a negative mass balance and added a deglaciation component to runoff in the Massa in 31 of the 43 years between 1922/23 and 1964/65 (Kasser, 1967). Despite some recovery in precipitation from the 1910s until the downturn at the end of the century, glaciers lost mass throughout, except in the mid-1960s to 1970s.

At the decadal level, total annual discharge in both Lonza and Rhône turned down into the 21st century, having peaked during 1987-96 and initially followed the upward trend in runoff from basins with $>10 \%$ glacier cover in Switzerland detected by Birsan and others (2005). Runoff in the Massa continued to increase, rising about $7 \%$ from 1987-96 to 1997-2006, but remained lower by a few per cent than in 1947-56, warmer conditions notwithstanding. These observations suggest that runoff from glacierized basins peaked in the first warming cycle in the late 1940s to early 1950s. Further warming in the second cycle increased flow, but to levels below those attained earlier.

\section{CONCLUSION}

Temporal patterns of variation of annual total runoff from Alpine basins from the late 19th through early 21 st centuries were influenced by the extent of basin glacierization. Runoff from (near-)ice-free basins generally reflected fluctuations of precipitation, rising to maxima between the late 1960s and early 1980s. Precipitation was, however, insufficient from the mid-19th through to the 21 st century to prevent glaciers losing mass throughout, except in the mid-1960s to 1970s.

The greater the basin glacier cover, the more runoff was influenced by thermal conditions through two periods of warming, from the early 20th century to the late 1940s-early 1950s, and again from the 1980s to the 2000s. Runoff from glacierized basins increased gradually from the late 19th century before rising rapidly in the 1940s, enhancing specific melt rates together with increasing precipitation opposing the effect of declining glacier area. After decreasing with falling temperatures to the late 1970s, rising runoff levels during the second warming period failed to exceed those attained during the first, higher summer temperatures notwithstanding. Although melt rates continued to increase, these were insufficient to offset reducing glacier surface areas exposed to melt, low or reducing levels of precipitation, and increasing evaporation, such that runoff from glacierized basins peaked in the late 1940s-early 1950s. It appears likely, if glaciers continue to recede with continued warming, that, without an increase in precipitation, runoff from glacierized Alpine basins will in future not exceed maxima attained in the mid-20th century.

\section{ACKNOWLEDGEMENTS}

The assistance of Bundesamt für Wasser und Geologie and MeteoSchweiz in making available discharge and meteorological records respectively, and of N. Scarle in producing the diagrams, is gratefully acknowledged.

\section{REFERENCES}

Bader, S. and H. Bantle. 2004. Das Schweizer Klima im Trend. Temperatur- und Niederschlagsentwicklung 1864-2001. Veröff. MeteoSchweiz 68.

Begert, M., T. Schlegel and W. Kirchhofer. 2005. Homogeneous temperature and precipitation series of Switzerland from 1864 to 2000. Int. J. Climatol., 25(1), 65-80.

Beniston, M. 2004. The 2003 heat wave in Europe: a shape of things to come? An analysis based on Swiss climatological data and model simulations. Geophys. Res. Lett., 31(2), L02202. (10.1029/2003GL018857.)

Beniston, M. and P. Jungo. 2002. Shifts in the distributions of pressure, temperature and moisture and changes in the typical weather patterns in the Alpine region in response to the behavior of the North Atlantic Oscillation. Theor. Appl. Climatol., 71(1-2), 29-42.

Birsan, M.-V., P. Molnar, P. Burlando and M. Pfaundler. 2005. Streamflow trends in Switzerland. J. Hydrol., 314(1-4), 312-329.

Bundesamt für Umwelt (BAFU). 2006. Hydrologisches Jahrbuch der Schweiz 2004. Bern, Schweizerische Eidgenossenschaft. Bundesamt für Umwelt.

Collins, D.N. 1989. Hydrometeorological conditions, mass balance and runoff from alpine glaciers. In Oerlemans, J., ed. Glacier fluctuations and climatic change. Dordrecht, etc., Kluwer Academic Publishers, 235-260.

Collins, D.N. 2006. Climatic variation and runoff in mountain basins with differing proportions of glacier cover. Nord. Hydrol., 37(4-5), 315-326.

Jansson, P., R. Hock and T. Schneider. 2003. The concept of glacier storage: a review. J. Hydrol., 282(1-4), 116-129.

Kasser, P. 1967. Fluctuations of glaciers 1959-1965 [Vol. I]. Paris, International Commission of Snow and Ice of the International Association of Scientific Hydrology/UNESCO.

Kasser, P. 1981. Rezente Gletschveränderungen in den Schweizer Alpen, Gletscher und Klima. In Jahrbuch der Schweizerischen Naturforschenden Gesellschaft, Wissenschaftlicher Teil, 1978. Basle, Birkhäuser Verlag, 106-138.

Landeshydrologie, Bundesamt für Wasser und Geologie. 1999. Nacheiszeitliche Gletschershwankungen. In Hydrologischer Atlas der Schweiz. Bern, Universität Bern, 3.8.

Maisch, M., A. Wipf, B. Denneler, J. Battaglia and C. Benz. 1999. Die Gletscher der Schweizer Alpen: Gletscherstand 1850 Aktuelle Vergletscherung - Gletscherschwund-Szenarien 21. Jahrhundert. Zürich, vdf Hochschulverlag AG an der ETH. (Schlussbericht NFP 31.)

Vincent, C., E. Le Meur, D. Six and M. Funk. 2005. Solving the paradox of the end of the Little Ice Age in the Alps. Geophys. Res. Lett., 32(9), L09706. (10.1029/2005GL022552.) 